\title{
Jeremy Corbyn: Why the British Labour Party is no Longer a Safe Place for Jews
}

\author{
Lesley Klaff \\ Sheffield Hallam University, England, UK
}

\begin{abstract}
On September 12, 2015, Jeremy Corbyn was elected leader of the Labour Party despite his history of jumping to the defence of blood libellers and conspiracy theorists, his friendship with Holocaust deniers, and his political embrace of antisemitic organisations. With Corbyn's election a phenomenon known as "anti-imperialist campism" became a prominent feature of the Labour Party. "Anti-imperialist campism" is characterized by stereotyped, disproportionate, and irrational hostility to Israel and Zionism. This caused the majority of Jewish Labour supporters to feel unsafe and in the new Labour Party both because Israel is a non-contingent aspect of Jewish identity and because "anti-imperialist campism" is considered to be antisemitic. Yet Jewish members who raised concerns about antisemitism in the Party were accused of dishonestly "playing the antisemitism card" in order to prevent criticism of Israel or to smear the Labour Party and undermine Corbyn's leadership. This response prevented antisemitism within the Party from being addressed and made those who had raised concerns feel excluded from the Party and the community of good, progressive people. Corbyn's failure to tackle antisemitism in the Labour Party continued until April 2016 when he reluctantly suspended two prominent members of parliament for antisemitism. An independent enquiry into antisemitism in the Labour Party was set up in May and its report is keenly awaited.
\end{abstract}

Keywords: Jeremy Corbyn, Labour Party, anti-imperialist campism, antisemitic anti-Zionism, the Livingstone Formulation

\section{Introduction}

Following Jeremy Corbyn's election to leader of the British Labour Party on September 12th, 2015, sociology lecturer and antisemitism scholar, David Hirsh (2015a), said that the "'new Labour Party' was no longer a safe place for Jews". ${ }^{1}$ Then, in October 2015, veteran activist and former UK Labour Party National Executive Committee member, Luke Akehurst, wrote in Fathom journal that Jeremy Corbyn's election to leader of the Labour Party had probably "done much damage... to the ability of Zionist Jewish activists to feel comfortable within the party" (Akehurst, 2015). Six months later, on March 15th, 2016, writing in The Guardian, journalist and Corbyn supporter, Owen Jones (2016), wrote that "[I]t cannot be acceptable that Jewish people feel uncomfortable in Labour...". Only a few days later, Jonathan Arkush, President of the Board of Deputies of British Jews, told the Evening Standard that "[F]rankly, most people in the Jewish community can't trust Labour" (Rocker, 2016, p. 5). The question is, why was Jeremy Corbyn's victory as

Lesley Klaff, LLB, M.A. of Socio-Legal Studies, Department of Law and Criminology, Sheffield Hallam University.

${ }^{1}$ At the moment, lots of Jews feel locked out of the party, both the Labour Party and also the carnival of joy and optimism. Your new Labour Party does not feel like a safe place for Jews. Imagine how that feels (Hirsh, 2015). 
leader of the Labour Party so deeply disturbing to the UK Jewish community?

\section{Corbyn's Labour Party and "Anti-Imperialist Campism"}

Jews have felt uncomfortable, fearful, lonely, and marginalised in the Labour Party since Corbyn was elected as leader on 12th September, 2015. This is because he represents a world view referred to as "anti-imperialist campism" and his 59\% landslide victory over the other three more moderate candidates marks the move of "anti-imperialist campism" from the fringes to the mainstream of the Labour Party. He won with a clear majority in every section of the party: amongst full members, trade union-affiliated supporters, and the new category of $£ 3$ registered voters (Hirsh, 2015b, pp. 6-7).

"Anti-imperialist campism", or "campism" for short, is a neologism coined by Professor Alan Johnson of BICOM to describe the Left's raising of "anti-imperialism" to an absolute value and the reframing of Israel as the key site of the imperialist system (Johnson, 2015). In the campist worldview terrorists are regarded as defensive forces against imperialism, that is, against the evils of Israel, as well as Britain and America (Hirsh, 2015 b, p. 5) ${ }^{2}$. Hirsh (2015b) refers to this perspective as being rooted in the "politics of position" rather than the "politics of reason" (pp. 1-24). Hirsh (2015b) observes that "anti-imperialist campism" has emerged as "the pre-eminent principle of the progressive movement" making hostility to Israel a key marker of political belonging (p. 2).

Anti-Israel hostility in the campist tradition has three components: first, a political programme, which aims to solve the Israel/Palestine conflict by means of a one-state solution - the replacement of Israel with Palestine; second, an intellectual discourse, which consists of a "system of distorting concepts, such as: 'Zionism is racism', Israel is a 'settler-colonialist state' which 'ethnically cleansed' the 'indigenous people' of Palestine, went on to create an 'apartheid state', and is now engaged in an 'incremental genocide' against the Palestinians" (Johnson, 2015, pp. 3-4). It also consists of Holocaust Inversion, the ugly and provocative comparison of Israelis with Nazis; and third, it comprises a global social movement, the BDS movement, and "campism" sits firmly within that (Johnson, 2015). This anti-Israel hostility is called "progressive anti-Zionism" or the "new anti-Zionism" by Anthony Julius (Julius, 2010, p. 584) and "antisemitic anti-Zionism" by Alan Johnson (2015, p. 3). Antisemitic anti-Zionism naturally upsets British Jews, the overwhelming majority of whom have a strong/moderate/mild attachment to Israel, according to recent figures produced by the Institute for Jewish Policy Research (Rocker, 2010). Those British Jews who are hostile to Israel and consider themselves to be anti-Zionist are either marginal or non-normative.

\section{Corbyn's Labour Party and Tolerance of Antisemitism}

Corbyn's "campism" is also marked by a tolerance for antisemitism and by the associated practice of characterizing accusations of antisemitism as a bad faith attempt to silence criticism of Israel. In other words, within Corbyn's Labour Party today, antisemitism is acceptable as long as it can plausibly appear to be criticism of Israel and/or supportive of the Palestinians, and anyone raising concerns about it within the party is denounced as an apologist for the oppression of the Palestinians (Hirsh, 2015b, pp. 4-5).

For example, the Labour electorate's tolerance of antisemitism can be seen in the fact that Corbyn was overwhelmingly elected as leader of the Labour Party despite his known association with antisemites.

\footnotetext{
${ }^{2}$ Indeed, to this day, Corbyn refuses to condemn the terrorist actions of the IRA and appointed John McDonnell, who suggested that members of the IRA should be "honored", as his Shadow Chancellor of the Exchequer (Hoare, 2015, p. 2).
} 
Corbyn's tolerance of antisemitism can be seen in the antisemitic friends he kept. He referred to the antisemitic Palestinian Islamist, Raed Saleh, whose promotion of the blood libel was at the time a matter of public record, as "an honored citizen who represents his people extremely well" and invited him to take tea on the terrace of the House of Commons. He embraced Hamas and Hezbollah as "friends" claiming that they were "bringing about long term peace and social justice and political justice to the whole region". 3 He financially supported a campaign called "Deir Yassin Remembered" which was run by Paul Eisen who came out as a Holocaust denier. In August 2015, at the height of his election contest, he planned to appear on a platform with the antisemitic cartoonist Carlos Latuff. This man had won second prize in President Ahmadinejad's Holocaust denial cartoon contest. He defended the conspiracy theorist Reverend Stephen Sizer against a charge of antisemitism by claiming that "he was under attack by a pro-Israeli smear campaign" (Simons, 2015) ${ }^{4}$ Sizer had blamed Israel for 9/11. Corbyn also worked for the Iranian state's antisemitic TV channel, Press TV.

Naturally enough during Corbyn's leadership campaign, concerns were raised about the company he kept and the fact that it reflected badly on him. The response of Corbyn and his faction was that he supports the Palestinians and those accusing him of antisemitism were trying to "smear" him to silence his criticism of Israel or to hurt his anti-austerity agenda (Hirsh, 2015b, p. 16). In other words, a political challenge was characterized as a personal attack (Hirsh, 2015b, p. 4). While no one accused Corbyn himself of being an antisemite he said: "The idea that I'm some kind of racist or anti-Semitic person is beyond appalling, disgusting and deeply offensive" (Jacobson, 2015). In this way, Corbyn portrayed himself as the unjust victim of an aggressive attack and avoided responding to the issue of antisemitism. According to Hirsh (2015), he thereby created a distinction between the "good people" inside his tent and the "bad people" outside it, who were mostly concerned Jewish Labour voters (p. 4). This made Jewish Labour Party supporters feel excluded from the community of good people by suggesting that they were apologists for the oppression of the Palestinians or were trying to hurt the Labour Party (Hirsh, 2015, p. 4).

\section{Corbyn's Labour Party and "The Livingstone Formulation"}

The accusation that Jews who raise concerns about antisemitism are "playing the antisemitism card" is known as "the Livingstone Formulation". It was named by David Hirsh after Ken Livingstone, the former Mayor of London, who in 2006 wrote in The Guardian, "[F]or far too long the accusation of antisemitism has been used against anyone who is critical of the policies of the Israeli government, as I have been" (Hirsh, 2010, p. 2). As Hirsh (2015) explains, it is a "rhetorical device that seeks to construe the raising of the issue of antisemitism as more suspect and inherently problematic than the phenomenon of antisemitism itself" (p. 2). Its use is widespread in the Labour Party because the so-called antiracist left is taught to think that talk about antisemitism is nothing more than the mobilisation of Jewish victim power and the playing of the Holocaust card to silence criticism of Israel (Hirsh, 2016a). So when on March 21st, Lord Levy challenged Corbyn to "deliver a specific and categoric condemnation of antisemitism", Corbyn responded by accusing Lord Levy of bad faith. He repeated the phrase "as Lord Levy knows full well" three times: "(1) that I oppose antisemitism; (2) that the Labour party opposes antisemitism; and (3) that we all oppose antisemitism. In other words, as Lord

\footnotetext{
${ }^{3}$ Corbyn also said at the time, "[W]e are opposed to Zionism and what Israel is doing towards the Palestinian people... They can't live if you've got Zionism dominating it all (Rich, 2016, p. 4).

4 According to Dave Rich, Corbyn alleged that there was "a wider pattern of demonising those who dare to stand up to and speak out against Zionism" (Hirsh, 2015, p. 16).
} 
Levy knows this "full well", then he must be "up to no good" (Hirsh, 2016a).

But despite his assurances, Corbyn does not oppose antisemitism (Liddle, 2016, p. 23). He continues to tolerate it. It's as if being an antisemite is not the very worst thing that one might be. ${ }^{5}$ On March 12th, The Telegraph reported that since he became Labour leader, Corbyn has held at least four meetings with a leading figure from Finsbury Park Mosque who blames Britain for ISIL, has called for the destruction of Israel, and has praised the recent wave of stabbings there (Gilligan, 2016). Then it was reported on March 14th that Vicki Kirby, a woman who was suspended from the Parliamentary Labour Party by Ed Miliband in 2014 for suggesting that ISIS should attack the "real oppressor" "evil Israel" and for tweeting that Hitler was the "Zionist God" and describing Jews as having "big noses", 6 had been readmitted to the Labour Party and elected as its vice-chair. It also emerged that she has been active in the Corbyn support network, Momentum. A photo of her and Corbyn, smiling happily together, was circulated online. The Labour Party did suspend her again but only following sharp condemnation from various sources, including left-wing journalist Owen Jones who called on the Labour Party to expel anyone found guilty of antisemitism (Jones, 2016). Similarly, in early March, a Labour Party member called Gerry Downing was expelled for antisemitism but only after David Cameron raised his case during Prime Minister's "Question Time" in the House of Commons. Downing had claimed on television that Zionism was at the heart of global capitalism and had advocated re-opening the "the Jewish Question”. Prior to his expulsion, he had been suspended for antisemitism and readmitted again.

The Kirby and Downing scandals followed on the heels of the resignation of Alex Chalmers from his position as Co-Chair of the Oxford University Labour Club (OULC) on the grounds that a large proportion of club members had "some kind of a problem with Jews" (Chalmers, 2016). Chalmers reported a culture in which Jewish students were mocked as "Zios", routinely baited with the song "Rockets over Tel Aviv", and in which support for Hamas was frequently voiced, while the concerns of Jewish students over Israeli Apartheid Week were frequently ridiculed. ${ }^{7}$ Specifically, a member of the club had argued that Hamas was justified in killing Jewish civilians and that all Jews were legitimate targets (MacEoin, 2016). According to Aaron Simons (2015), a former president of the Oxford University Jewish Society, "[A] committee member stated that all Jews should be expected to publicly denounce Zionism and the state of Israel, and that we should not associate with any Jew who fails to do so". Chalmers blamed the antisemitic incidents in the Club on the culture that allowed them to be normalized, citing "the poisonous ideology of antisemitic anti-Zionism" and the practice of the Livingstone Formulation as the root causes (Chalmers, 2016). The former Co-Chair of the Club told Jewish students who raised concerns about antisemitism that "most accusations of antisemitism are you Zionists crying wolf". 8

Remarks made by the newly elected president of the National Union of Students, Malia Bouattia, are further evidence of the normalization of antisemitism in student politics. She referred to her alma mater, the University of Birmingham, as a "Zionist outpost" with "the largest JSoc in the country" and described the government's anti-extremist Prevent strategy as the result of "all manner of Zionist and neo-con lobbies"

\footnotetext{
5 This was something many on the left were willing to concede even in the late 1930s. According to George Sack's "Jewish Question", a volume of the Left Book Club published in 1937 told its readers: "Hate the Jew if you must, but do not allow your hatred to make you the victim of the fascist who, on the plea that he also hates the Jew, makes you his accomplice in worse crimes" (Julius, 2010, p. 588).

${ }^{6}$ Candidate who suggested that Isis should attack Israel readmitted to Labour. Retrieved March 14, 2016, from http://www.order-order.com/2016/03/14/candidate-who-suggested-isis-should-attack-israel-readmitted-to-labour. Vicki Kirby tweeted: "We invented Israel when saving them from Hitler, who now seems to be their new teacher". Ibid.

7 Ibid.

8 Alex Chalmers' Facebook post giving the reasons for his resignation, 15th February 2016.
} 
(Johnson, 2016a, p. 2). She warned against "mainstream Zionist-led media outlets" and said she supported violence against Jews in Israel (Hirsh, 2016bc, p. 1). This prompted a group of Jewish students to write an open letter expressing their concern over "Malia's record of anti-Semitism [and her] virulent strain of anti-Zionism" (Hirsh, 2016c, p. 1).

It is clear that the mainstreaming of anti-imperialist campism within the Labour Party since Jeremy Corbyn became leader has led to a permissive environment in which large sections of the Party, including Labour supporting university students, feel entitled to make outrageous statements about Israel or Israeli Jews or Jews who support Israel. The Labour Party cannot honestly hold itself out as an "anti-racist party, committed to combating and campaigning against all forms of racism, including antisemitism [...]"9 as long as it continues to tolerate left-wing antisemitism in the form of antisemitic anti-Zionism.

Indeed, as early in his leadership as October 2015, Corbyn chose to take no action against Labour Party MP and Father of the House, Gerald Kaufman, for blatant antisemitism. He told members of the Palestine Return Centre that "Jewish money" had bought the silence of the Conservative Government with respect to Israel's "crimes" and that the Israeli government had fabricated more than half of the stabbings in the recent stabbing intifada to justify the execution of innocent Palestinians. ${ }^{10}$ Other Labour MPs who were present at the meeting, Shadow Justice Minister Andy Slaughter, and former Labour MP for Battersea, Martin Linton, tolerated Kaufman's comments by applauding him. Hirsh (2016c) has noted that Kaufman's, Downing's and Kirby's worldviews are related to those of Corbyn and Livingstone and has suggested that this may be why their antisemitism is tolerated and why concerns raised about it are interpreted as a smear campaign (p. 2).

\section{Corbyn Reluctantly Suspends Prominent MPs for Antisemitism}

It was not until 27th April, 2016, that the Labour Party finally responded to the antisemitism within its ranks when it suspended the Labour MP for Bradford West, Naz Shah, for making remarks that were both anti-Israel and anti-Jewish. She said that Israeli Jews should be "relocated" to America, compared Israelis to Hitler, issued public warnings that "the Jews are rallying", compared Zionism to al-Quaeda, and was worried that the Zionists were "grooming" Jews to "exert political influence at the highest levels of public office" (Johnson, 2016). Dr. Denis MacEoin (2016) observed that Shah's approval of a proposal to "transport" the Jews of Israel to America as the "solution" to the Palestinian problem carried echoes of Reinhard Hedrich's antisemitism (p. 5). Corbyn, however, said nothing about Shah's comments other than that he accepted her "fulsome apology" and only suspended Shah following pressure from David Cameron in the House of Commons (Stewart, 2016) ${ }^{11}$. Johnson believes that Shah is just the symptom of the disease caused by the antisemitic anti-Zionism that is gripping the Labour Party under Jeremy Corbyn's leadership (Johnson, 2015).

The second Labour MP to be suspended was Ken Livingstone, who sprang to Shah's defence by arguing that Hitler was a Zionist. In an interview with the BBC on 28th April, Livingstone said, "Let's remember when

\footnotetext{
${ }^{9}$ Labour Party Code of Conduct as adopted by Labour's National Executive Committee. Retrieved June 10,2016 from http://www.labour.org.uk/index.php/chakrabarti

10 Following letters to Corbyn and his Chief Whip from Jewish communal organisations, a petition signed by over 1,000 grassroots activists and a letter by eight Labour MPs sent on behalf of the All-Party ParliamentaryGroup against Antisemitism, Corbyn finally stated publicly that Kaufman's remarks were "unacceptable and regrettable" and that the Labour Party would "not tolerate antisemitism or Islamophobia".

${ }^{11}$ Shah also resigned from her role as a parliamentary assistant to the Shadow Chancellor, John McDonnell, and told MPs, "I wholeheartedly apologise to this house for the words I used before I became a member. I accept and understand that the words I used caused upset and hurt to the Jewish community and I deeply regret that" (Stewart, 2016).
} 
Hitler won his election in 1932 his policy then was that Jews should be moved to Israel. He was supporting Zionism. This is before he went mad and ended up killing six million Jews" (MacEoin, 2016). According to MacEoin (2016), Livingstone's statement was "a perfect conflation of anti-Israel hatred and Nazi-style racism". Depsite this, Jeremy Corbyn did not want to suspend Livingstone and only did so under immense pressure from senior shadow cabinet figures and Jewish groups (Pettitt, 2016). On this occasion the Livingstone Formulation failed to rescue Livingstone (Hirsh, 2015a).

\section{Conclusions}

Following the suspension of Shah and Livingstone for their antisemitic remarks, it was reported by the press that the Labour Party secretly suspended 50 of its members for antisemitism (MacEoin, 2016, p. 1). This led to the setting up of an independent inquiry into Labour Party antisemitism under the leadership of Shami Chakrabarti, former head of the campaign group Liberty ${ }^{12}$. The inquiry was announced as critics claimed that the Party leadership was not doing enough to tackle the problem of antisemitism.

That Corbyn was not doing enough to tackle antisemitism was an accurate perception. It was not enough for Corbyn to say that he opposed antisemitism. He had to show that he understood the ways in which hostility to Israel and Zionism are linked to antisemitism, and this he failed to do. He preferred to characterize all criticism of Israel as legitimate and to view concerns about antisemitism as a campaign to smear him and the Labour Party, or as an attempt to play the "antisemitism card" in order to silence criticism of Israel. It is fervently hoped that the Shami Chakrabarti inquiry will engage in good faith with the evidence of antisemitism submitted to it by Jews and non-Jews alike. As left-wing journalist Owen Jones (2016) has said, "[I]t is incumbent on the progressively minded to take antisemitism seriously. We wouldn't belittle other forms of bigotry or seek to deflect from it. Discussion about serious antisemitism should not be launched into a debate about Israel".

The inquiry is due to report its findings shortly. If it acknowledges that the grossly distorted discourse about Israel that is endemic to large sections of the Labour Party is in fact antisemitic and promulgates clear protocols to identify and prevent it, then and only then, will Jews feel comfortable and safe in Jeremy Corbyn's Labour Party.

\section{References}

Akehurst, L. (2015). What does the "Corbyn Revolution" mean for the UK Left and Israel? Fathom, Autumn. Retrieved from http://fathomjournal.org/what-does-the-corbyn-revolution-mean-for-the-uk-left-and-israel

Chalmers, A. (2016). Antisemitic anti-Zionism and the scandal of the Oxford University Labour Club. Fathom, Spring. Retrieved from http://fathomjournal.org/antisemitic-anti-Zionism-and-the-scandal-of-oxford-university-labour-club

Gilligan, A. (2016). Jeremy Corbyn and the mosque leader who blames the UK for Isil. The Telegraph, March 12. Retrieved from http://www.telegraph.co.uk/news/politics/Jeremy/Corbyn/1219229/Jeremy-Corbyn-and-the-mosque-leader-who-blames-theUK-for-isil.html

Hirsh, D. (2010). Accusations of malicious intent in debates about the Palestine-Israel conflict and about antisemitism: The Livingstone Formulation, "playing the antisemitism card" and contesting the boundaries of antiracist discourse. Transveral, Graz, 1, 47-77.

Hirsh, D. (2015a). Mr. Corbyn, time to say you were wrong. The Jewish Chronicle. Retrieved September 17, 2015, from http://www.thejc.com/comment-and-debate/comment/145121/mr-corbyn-time-to-say-you-were-wrong

\footnotetext{
${ }^{12}$ In addition to antisemitism, the inquiry is also considering evidence of other forms of racism and Islamophobia.
} 
Hirsh, D. (2015b). The Corbyn left: The politics of position and the politics of reason. Fathom, Autumn. Retrieved from http://fathomjournal.org/the-corbyn-left-the-politics-of-position-and-the-politics-of-reason

Hirsh, D. (2016a). Jew hate and today's left. The Jewish Chronicle Online. Retrieved March 17, 2016, from http://www.thejc.com.news/uk-news/154672/jew-hate-and-today's-left

Hirsh, D. (2016b). Corbyn refuses to address the specifics of antisemitism and he accuses Lord Levy of bad faith. Engage. Retrieved March 21, from http://www.engageonline.wordpress.com/2016/03/21/corbyn-refuses-to-address-the-specifics-of-antisemitism-and-he-accuse s-lord-levy-of-bad-faith-david-hirsh

Hirsh, D. (2016c). The livingstone formulation fails to rescue livingstone. Engage. Retrieved April 28, 2016, from https://engageonline.wordpress.com/2016/04/28/the-livingstone-formulation-david-hirsh-

Hoare, L. (2015). Western Europe's most powerful anti-Zionist. The Tower, 21. Retrieved from http://www.thetower.org/article/western/-europes-most-powerful-anti-Zionist/

Jacobson, H. (2015). Corbyn may say he's not anti-Semitic, but associating with the people he does is its own crime. Independent. Retrieved September 4, 2015, from http://www.independent.co.uk/voices/corbyn-may-say-he-is-not-anti-semeticbut-associating-with-the-people-he-does-is-its-own-crime-10487318.html

Johnson, A. (2015). No Jeremy Corbyn is not antisemitc - but the left should be wary of who he calls friends. New Statesman, September 2, 2015. Retrieved from http://www.newstatesman.com/politics/staggers/2015/09/no-jeremycorbyn-not-antisemitic-left-should-be-wary-who-he-calls-friends

Johnson, A. (2015). The left and the Jews: Time for a rethink. Fathom, Autumn. Retrieved from http://fathomjournal.org/the-left-and-the-jews-time-for-a-rethink/

Johnson, A. (2016a). Jeremy Corbyn is incapable of tacking Labour's anti-Semitism problem. Prospect. Retrieved April 25, 2016, from http://www.prospectmagazine.co.uk/politics/jeremy-corbyn-is-incapableof-tackling-labours-anti-semitism-problem

Johnson, A. (2016b). Naz Shah is only a symptom of the anti-Semitic disease that's gripping the left. Retrieved April 28, 2016, from http://www.politics.co.uk/comment-analysis/2016/04/28/naz-shah-is-only-a-symptom-of-the-antisemitic-disease-that-s

Jones, O. (2016). Antisemitism is a poison the left must take leadership against it. Opinion, The Guardian. Retrieved March 15, 2016, from http:// www.theguardian.com/commentisfree/2016/mar/15/antisemitism-israel-policies-labour-activist-vicki-kirby

Julius, A. (2010). Trials of the Diaspora: A History of Anti-Semitism in England. Oxford University Press.

Liddle, R. (2016). Corbyn's Labour where all forms of bigotry are reviled—except one. Comment, Sunday Times, March 20.

MacEoin, D. (2016). Anti-semitism in the UK Labour Party. Gatestone Institute. Retrieved May 4, 2016, from http://www.gatestoneinstitute.org/7977/antisemitism-uk-labour

Pettit, J. (2016). Ken livingstone suggests Jeremy Corbyn did not want to suspend him from Labour over Hitler row. The Sun, Retrieved June 2, 2016, from http://www.thesun.co.uk/news/1231326/ken-livingstone-suggests-jeremycorbyn-did-not-want-to-suspend-him-from-labour-over-hitler-row

Rich, D. (2016). What that interview revealed about the left. The Jewish Chronicle, March 25, 2016.

Rocker, S. (2010). Israel attitudes survey: Most are happy to be Zionists. The Jewish Chronicle. Retrieved July 15, 2010, from http://www.thejc.com/news/uk-news/35730/israel-attitudes-survey-most-are-happy-be-zionists

Rocker, S. (2016). Arkush criticised for comments about trust. The Jewish Chronicle, March 25, 2016.

Simons, J. W. (2015). Jeremy Corbyn defends a controversial vicar who was banned from social media for sharing "clearly anti-Semitic" material blaming Israel for 9/11 attacks. Daily Mail, August 10, 2015.

Stewart, H. (2016). Naz Shah suspended by Labour party amid antisemitism row. The Guardian, April 27, 2016. Retrieved from http://www.theguardian.com/politics/2016/apr/27.naz-shah-suspended-labour-party-antisemitism-row 